\title{
Impact of Coastal Erosion in the Coastal Area of Rembang, Central Java
}

\section{Lintang Ronggowulan', Sarwono1, Chatarina Muryani', Yunus Aris Wibowo²}

${ }^{1}$ Universitas Sebelas Maret Surakarta, ${ }^{2}$ Universitas Muhammadiyah Surakarta lintang_ronggowulan@staff.uns.ac.id

\section{Article History}

accepted 31/08/2020

approved 22/09/2020

published 28/10/2020

\begin{abstract}
On the one hand, the coastal area promises abundant natural resources, but on the other hand, there are potential threats of disaster for the people living in that area. Coastal erosion or abrasion is a threat/danger that harmful to communities in coastal areas in Indonesia. One of the areas affected by abrasion in Indonesia is Rembang Regency. This study attempted to analyze the physical and social impacts of abrasion in the Rembang Regency. This study was conducted qualitatively by utilizing Ikonos High-Resolution Satellite Imagery, field surveys, and interviews as the basis for the analysis of the impact of the abrasion disaster. Respondents in this study were communities and government officials in areas affected by abrasion which were determined by purposive sampling technique. The results of the data analysis show that the physical impacts of abrasion are classified into four categories, namely heavy damage, moderate damage, minor damage, and no damage, while the social impacts are in the form of psychological, sociological, and economic disturbances which have implications for decreasing welfare. Therefore, an in-depth analysis is needed to determine the abrasion disaster management policy in Rembang Regency.
\end{abstract}

Keywords: Abrasion, Coastal Erosion, Disaster, Coastal, Rembang

\begin{abstract}
Abstrak
Wilayah kepesisiran di satu sisi menjanjikan sumberdaya alam yang melimpah, namun sebaliknya terdapat potensi ancaman bencana bagi masyarakat yang tinggal di wilayah tersebut. Erosi pantai atau abrasi merupakan salah satu ancaman/bahaya yang berpotensi menimbulkan kerugian bagi masyarakat di wilayah kepesisiran di Indonesia. Salah satu wilayah terdampak abrasi di Indonesia adalah Kabupaten Rembang. Studi ini mencoba untuk menganalisis dampak fisik dan sosial bencana abrasi di Kabupaten Rembang. Studi ini dilaksanakan secara kualitatif dengan memanfaatkan Citra Satelit Resolusi Tinggi Ikonos, survei lapangan dan wawancara sebagai dasar analisis dampak bencana abrasi. Responden dalam studi ini adalah masyarakat dan pejabat pemerintahan di wilayah terdampak bencana abrasi yang ditentukan dengan teknik purposive sampling. Hasil analisis data menunjukkan bahwa dampak fisik akibat bencana abrasi diklasifikasikan menjadi empat kategori, yaitu rusak berat, rusak sedang, rusak ringan dan tidak ada kerusakan, sedangkan dampak sosial berupa gangguan secara psikologis, sosiologis, ekonomi yang berimplikasi pada penurunan kesejahteraan. Oleh karena itu, diperlukan analisis mendalam untuk menentukan kebijakan penanggulangan bencana abrasi di Kabupaten Rembang.
\end{abstract}

Kata kunci: Abrasi, Erosi Pantai, Bencana, Pesisir, Rembang

Social, Humanities, and Education Studies (SHEs): Conference Series https://jurnal.uns.ac.id/shes

p-ISSN 2620-9284

e-ISSN 2620-9292 


\section{PENDAHULUAN}

Bencana merupakan suatu fenomena yang merugikan atau mengganggu aktivitas manusia. Ditinjau dari penyebabnya, bencana dikategorikan menjadi bencana alam dan non alam. Bencana alam merupakan fenomena alam yang merugikan karena mengakibatkan komponen risiko terpapar, sedangkan bencana non alam diakibatkan oleh kegagalan teknologi, wabah atau konflik social (BNPB, 2012). Oleh karena itu, baik fenomena alam maupun non alam dikategorikan sebagai bencana jika menimbulkan kerugian bagi masyarakat baik properti, mental bahkan korban jiwa (Wibowo et al., 2019).

Peraturan Kepala Badan Nasional Penanggulangan Bencana (PERKA BNPB) Nomor 2 Tahun 2012 mengklasifikasikan 13 jenis bencana, yaitu gempabumi, tsunami, banjir, tanah longsor, letusan gunungapi, gelombang ekstrim dan abrasi, cuaca ekstrim, kekeringan, kebakaran hutan dan lahan, kebakaran gedung dan pemukiman, epidemi dan wabah penyakit, gagal teknologi serta konflik sosial. 13 jenis bencana tersebut semuanya pernah terjadi di Indonesia dan menyebabkan kerugian yang bervariasi tergantung pada magnitud dan komponen risiko yang terpapar. Salah satu kejadian bencana yang mengakibatkan kerugian secara masif bagi masyarakat adalah erosi pantai atau sering disebut sebagai abrasi.

Erosi pantai atau abrasi merupakan bagian dari dinamika wilayah kepesisiran sebagai konsekuensi dari pengaruh kondisi geologi, energi gelombang, arus laut pasang surut, angin, aktivitas manusia dan perubahan iklim (Davidson-Arnott, 2010; Kerguillec et al., 2019; Marchesiello et al., 2019; Mukhopadhyay et al., 2018; RangelBuitrago et al., 2018; Toimil et al., 2020; Venancio et al., 2020). Erosi pantai atau abrasi merupakan dinamika negatif wilayah kepesisiran karena mengakibatkan bagian daratan berkurang (Gomez et al., 2020; Leatherman, 2018). Berkurangnya daratan di wilayah kepesisiran dalam kondisi tertentu tidak bisa dikategorikan sebagai bencana, tetapi hanya termasuk proses geomorfologi (Davidson-Arnott, 2010; Rangel-Buitrago et al., 2020; et al., 2018). Namun demikian, jika fenomena tersebut mencapai wilayahwilayah yang dimanfaatkan oleh masyarakat dan mengakibatkan kerugian maka bisa dikategorikan sebagai bencana alam (Dewi \& Bijker, 2020). Erosi pantai atau abrasi termasuk bencana alam karena proses dan energi penyebabnya berasal dari alam.

Bencana erosi pantai atau abrasi secara spesifik akan mengakibatkan kerugian bagi masyarakat yang bermukim dan beraktivitas di wilayah kepesisiran (Mukhopadhyay et al., 2018; Sinitsyn et al., 2020). Indonesia merupakan salah satu negara dengan garis pantai terpanjang di dunia. Fakta tersebut di satu sisi sangat menguntungkan karena Indonesia sangat kaya sumberdaya alam kepesisiran dan laut. Akan tetapi, di sisi lain banyak kejadian-kejadian (bahaya/ancaman) yang berpotensi merugikan masyarakat (Marfai \& King, 2008; Triyanti et al., 2017). Salah satu wilayah terdampak erosi pantai atau abrasi terparah di Indonesia adalah Provinsi Jawa Tengah khususnya wilayah kepesisiran utara . Tercatat kota/kabupaten di sepanjang wilayah kepesisiran utara Provinsi Jawa Tengah mengalami kejadian abrasi, meskipun dalam intensitas dan frekuensi yang berbeda-beda. Kabupaten Rembang merupakan salah satu kabupaten di Provinsi Jawa Tengah yang terdampak abrasi.

Enam Kecamatan di Kabupaten Rembang (Kecamatan Kaliori, Kecamatan Rembang, Kecamatan Lasem, Kecamatan Sluke, Kecamatan Kragan dan Kecamatan Sarang) berbatasan langsung dengan Laut Jawa, dengan Panjang garis pantai 63 kilometer (BPS (The Indonesian Central Bureau for Statistics), 2018). Ditinjau dari karakteristik fisiknya maka Kabupaten Rembang sangat rawan terhadap erosi pantai atau abrasi. Tercatat pada Tahun 2014, 65 rumah rusak dengan kategori ringan hingga berat akibat abrasi lebih dari satu kilometer (Muria News, 2014). Selain itu, gangguan juga dialami secara psikologis oleh masyarakat terdampak abrasi sebagai dampak sekunder kerugian secara fisik (material) (Domingues et al., 2018). Sebagai Langkah awal untuk menanggulangi permasalahan tersebut diperlukan analisis dampak erosi 
pantai atau abrasi secara fisik dan social (Toimil et al., 2020). Oleh karena itu, studi ini fokus untuk menganalisis dampak erosi pantai atau abrasi secara fisik dan social di wilayah kepesisiran Kabupaten Rembang. Analisis dampak dilakukan menggunakan teknologi Penginderaan Jauh (PJ) dengan memanfaatkan Citra Satelit Reolusi Tinggi (CSRT) dan wawancara terhadap masyarakat terdampak (Gomez et al., 2020; Kerguillec et al., 2019; Marchesiello et al., 2019; Sun et al., 2020). Pemanfaatan teknologi PJ dipilih karena terbukti efektif digunakan untuk analisis bencana di wilayah kepesisiran dengan biaya relatif murah (Dewi \& Bijker, 2020). Luaran yang diharapkan dari studi ini adalah distribusi wilayah terdampak erosi pantai atau abrasi dan jenis kerugian/kerusakan yang ditimbulkan. Lebih lanjut, luaran tersebut dapat dijadikan dasar sebagai bahan pertimbangan dalam pengambilan keputusan penanggulangan bencana erosi pantai atau erosi pantai khususnya di wilayah kepesisiran Kabupaten Rembang (Dunning, 2020; Kerguillec et al., 2019; Nurhidayah \& Mcllgorm, 2019; Rumson et al., 2017; Toimil et al., 2020).

\section{METODE}

Studi ini termasuk jenis penelitian deskriptif kualitatif.dan dilaksanakan di sebagian wilayah kepesisiran Kabupaten Rembang yang terdiri dari Kecamatan Kragan dan Sarang. Kedua kecamatan tersebut dipilih karena merupakan wilayah terdampak bencana erosi pantai atau abrasi terparah di Kabupaten Rembang. Data primer yang digunakan dalam studi ini adalah hasil survei validasi wilayah terdampak, hasil wawancara dan dokumentasi lapangan, sedangkan data sekunder yang digunakan di antaranya CSRT, Peta Rupa Bumi Indonesia serta data kependudukan. Responden dalam studi ini dipilih dengan Teknik purposive sampling. Responden adalah masyarakat terdampak bencana erosi pantai atau abrasi di Kecamatan Kragan dan Sarang. Selain itu, wawancara dan kuesioner juga dilakukan terhadap pejabat pemerintahan lokasi terdampak (Dunning, 2020). Pengumpulan data dari responden menggunakan wawancara terstruktur dan kuesioner (Bañas et al., 2020; Chiang \& Chang, 2018; Dunning, 2020; Landry et al., 2020; Nadzir et al., 2014; Senevirathna et al., 2018). CSRT yang dipilih dalam studi ini adalah Ikonos dengan pertimbangan resolusi spasial dan temporalnya representatif untuk digunakan sebagai acuan analisis perubahan garis pantai akibat abrasi (Sun et al., 2020). Pemanfaatan Citra Ikonos untuk analisis dampak erosi pantai atau abrasi dapat dilakukan dengan melakukan pengamatan perubahan garis pantai secara spasio-temporal (Ahmed et al., 2018; Trembanis et al., 2020). Hasil interpretasi tersebut selanjutnya divalidasi di lapangan secara langsung untuk mendapatkan data perubahan garis pantai dan dampaknya secara akurat (Sánchez-García et al., 2017). Sampel yang digunakan sebagai uji validasi di lapangan ditentukan sesuai populasi berdasarkan jumlah lokasi terdampak erosi pantai hasil interpretasi Citra Ikonos. Keabsahan data dilakukan melalui triangulasi Teknik, yaitu dengan melakukan wawancara, pengisian kuesioner dan survei lapangan. Data hasil wawancara dan interpretasi Citra Ikonos selanjutnya ditabulasi dan disajikan secara deskriptif dalam bentuk tabel dan gambar.

\section{HASIL DAN PEMBAHASAN}

\section{Dampak Fisik Erosi Pantai}

Dampak fisik erosi pantai atau abrasi merupakan dampak yang mengakibatkan perubahan negatif / mundurnya garis pantai yang menyebabkan kerusakan fisik berupa kerusakan bangunan, tambak dan pusat perdagangan. Dampak secara fisik diidentifikasi secara visual melalui interpretasi Citra Ikonos. Hasil interpretasi secara kualitatif kemudian dibuktikan kebenarannya di lapangan di 18 lokasi. 13 lokasi terletak 
di Kecamatan Kragan dan lima titik di Kecamatan Sarang (Tabel 1). Lebih lanjut, wawancara dilakukan terhadap 40 warga dan perwakilan perangkat desa dari seluruh desa terdampak abrasi sesuai pada lokasi pengamatan (validasi). Pemilihan responden tersebut dilakukan untuk mendapatkan data otentik di lapangan dari para korban terdampak dan pemerintah sebagai penentu kebijakan (Leatherman, 2018; Senevirathna et al., 2018).

Tabel 1. Dampak Abrasi Di Wilayah Kepesisiran Kragan Dan Sarang

\begin{tabular}{|c|c|c|c|c|c|}
\hline No. & Kecamatan & Desa & $\begin{array}{l}\text { Jenis Objek } \\
\text { Terdampak }\end{array}$ & Tingkat kerusakan & Lokasi Pengamatan \\
\hline \multirow[t]{13}{*}{1.} & \multirow[t]{13}{*}{ Kragan } & Sumbersari & $\begin{array}{l}\text { Permukiman, } \\
\text { Pabrik, Tambak }\end{array}$ & $\begin{array}{l}\text { Rusak berat (Hilangnya } \\
\text { bangunan, hilangnya } \\
\text { tambak) }\end{array}$ & $\begin{array}{l}06^{\circ} 38^{\prime} 44,15^{\prime \prime} \text { dan } 111^{\circ} \\
34^{\prime} 04,88^{\prime \prime}\end{array}$ \\
\hline & & Sumurtawang & Permukiman & Rusak sedang & $\begin{array}{l}06^{\circ} 39^{\prime} 06,33^{\prime \prime} \text { dan } 111^{\circ} \\
34^{\prime} 33,53^{\prime \prime}\end{array}$ \\
\hline & & $\begin{array}{l}\text { Pandangan } \\
\text { Kulon }\end{array}$ & Permukiman & Rusak sedang & $\begin{array}{l}06^{\circ} 39^{\prime} 45,41^{\prime \prime} \text { dan } 111^{\circ} \\
35^{\prime} 12,58^{\prime \prime}\end{array}$ \\
\hline & & $\begin{array}{l}\text { Pandangan } \\
\text { Wetan }\end{array}$ & $\begin{array}{l}\text { Bangunan } \\
\text { nelayan }\end{array}$ & Rusak sedang & $\begin{array}{l}6^{\circ} 40^{\prime} 03,22^{\prime \prime} \text { dan } 111^{\circ} \\
35^{\prime} 33,96^{\prime \prime}\end{array}$ \\
\hline & & Plawangan & $\begin{array}{l}\text { Kemunduran } \\
\text { garis pantai kea } \\
\text { rah darat }\end{array}$ & Rusak ringan & $\begin{array}{l}06^{\circ} 40^{\prime} 07,39^{\prime \prime} \text { dan } 111^{\circ} \\
35^{\prime} 38,52^{\prime \prime}\end{array}$ \\
\hline & & Balungmulyo & Tidak ada & Tidak ada & $\begin{array}{l}06^{\circ} 40^{\prime} 30,9^{\prime \prime} \text { dan } 111^{\circ} \\
36^{\prime} 11,7^{\prime \prime}\end{array}$ \\
\hline & & Tegalmulyo & Permukiman & Rusak ringan & $\begin{array}{l}06^{\circ} 41^{\prime} 01,94^{\prime \prime} \text { dan } 111^{\circ} \\
36^{\prime} 37,46^{\prime \prime}\end{array}$ \\
\hline & & Kragan & Permukiman & $\begin{array}{l}\text { Rusak berat (Hilangnya } \\
\text { bangunan) }\end{array}$ & $\begin{array}{l}06^{\circ} 41^{\prime} 36,69^{\prime \prime} \text { dan } 111^{\circ} \\
37^{\prime} 16,31^{\prime \prime}\end{array}$ \\
\hline & & Karangharjo & Permukiman & Rusak ringan & $\begin{array}{l}06^{\circ} 41^{\prime} 55,38^{\prime \prime} \text { dan } 111^{\circ} \\
37^{\prime} 35,17^{\prime \prime}\end{array}$ \\
\hline & & Karanglincak & $\begin{array}{l}\text { Kemunduran } \\
\text { garis pantai kea } \\
\text { rah darat }\end{array}$ & Rusak ringan & $\begin{array}{l}06^{\circ} 42^{\prime} 02,47^{\prime \prime} \text { dan } 111^{\circ} \\
37^{\prime} 42,88^{\prime \prime}\end{array}$ \\
\hline & & Mojokerto & $\begin{array}{l}\text { Kemunduran } \\
\text { garis pantai kea } \\
\text { rah darat }\end{array}$ & Rusak ringan & $\begin{array}{l}06^{\circ} 42^{\prime} 03,22^{\prime \prime} \text { dan } 111^{\circ} \\
37^{\prime} 55,46^{\prime \prime}\end{array}$ \\
\hline & & Kebloran & $\begin{array}{l}\text { Kemunduran } \\
\text { garis pantai kea } \\
\text { rah darat }\end{array}$ & Rusak ringan & $\begin{array}{l}06^{\circ} 42^{\prime} 18,54^{\prime \prime} \text { dan } 111^{\circ} \\
38^{\prime} 05,67^{\prime \prime}\end{array}$ \\
\hline & & Tanjung & $\begin{array}{l}\text { Kemunduran } \\
\text { garis pantai kea } \\
\text { rah darat }\end{array}$ & Rusak ringan & $\begin{array}{l}06^{\circ} 42^{\prime} 29,20^{\prime \prime} \text { dan } 111^{\circ} \\
38^{\prime} 13,51^{\prime \prime}\end{array}$ \\
\hline \multirow[t]{5}{*}{2.} & \multirow[t]{5}{*}{ Sarang } & Kalipang & $\begin{array}{l}\text { Permukiman, } \\
\text { Kantor } \\
\text { Pemerintahan }\end{array}$ & $\begin{array}{l}\text { Rusak berat (Hilangnya } \\
\text { bangunan, hilangnya } \\
\text { tambak) }\end{array}$ & $\begin{array}{l}06^{\circ} 42^{\prime} 57,65^{\prime \prime} \text { dan } 111^{\circ} \\
38^{\prime} 45,58^{\prime \prime}\end{array}$ \\
\hline & & Sendangmulyo & Tidak ada & Tidak ada & $\begin{array}{l}06^{\circ} 43^{\prime} 53,6^{\prime \prime} \text { dan } 111^{\circ} \\
39^{\prime} 50,5^{\prime \prime}\end{array}$ \\
\hline & & Bajingjowo & Permukiman & Rusak ringan & $\begin{array}{l}06^{\circ} 44^{\prime} 20,13^{\prime \prime} \text { dan } 111^{\circ} \\
40^{\prime} 23,78^{\prime \prime}\end{array}$ \\
\hline & & Karangmangu & Permukiman & Rusak berat & $\begin{array}{l}06^{\circ} 44^{\prime} 23,36^{\prime \prime} \text { dan } 111^{\circ} \\
40^{\prime} 26,99^{\prime \prime}\end{array}$ \\
\hline & & Temperak & $\begin{array}{l}\text { Permukiman, } \\
\text { masjid dan } \\
\text { makam }\end{array}$ & Rusak berat & $\begin{array}{l}06^{\circ} 45^{\prime} 08,2^{\prime \prime} \text { dan } 111^{\circ} \\
41^{\prime} 20,6^{\prime \prime}\end{array}$ \\
\hline
\end{tabular}

Sumber: - Interpretasi Citra Ikonos

- Survei Lapangan 

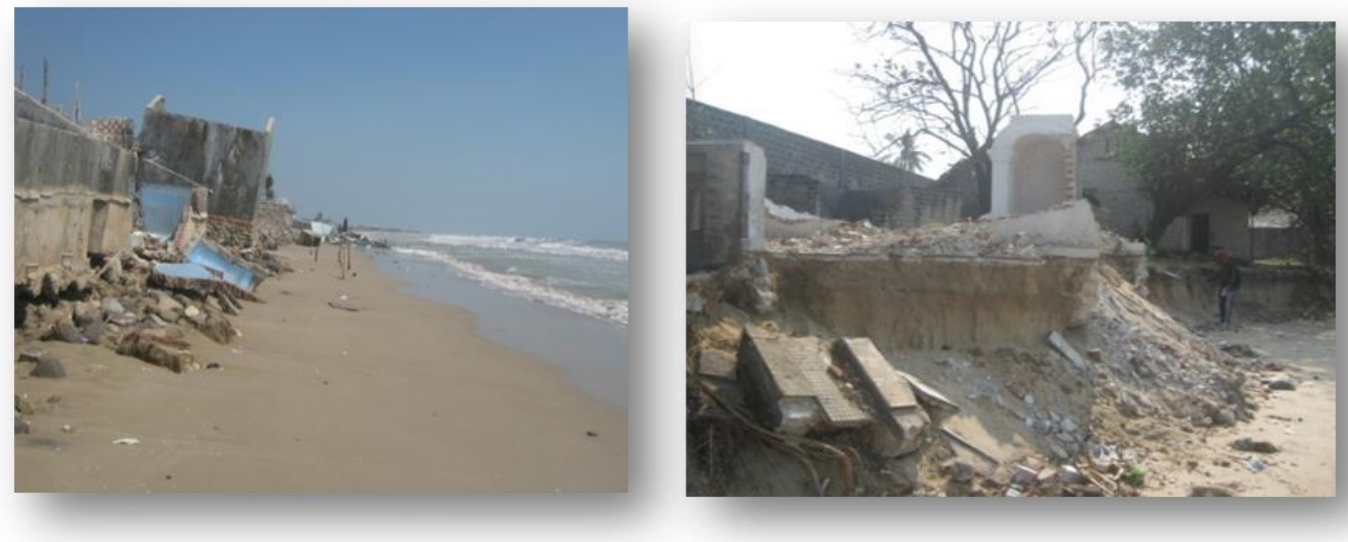

Gambar 1. Pabrik Tambak Udang dan Masjid yang Rusak Akibat Abrasi di Rembang

Hasil interpretasi dan validasi di lapangan diperoleh empat kelas dampak erosi pantai atau abrasi di wilayah kepesisiran Kragan dan Sarang di antaranya rusak berat, rusak sedang, rusak ringan dan tidak ada kerusakan (Gambar 1). Kategori rusak berat mengakibatkan hilangnya bangunan (permukiman), kantor pemerintahan, pabrik dan tambak. Kategori rusak sedang mengakibatkan kerusakan pada permukiman tetapi tidak sampai mengakibatkan bangunan roboh atau hanyut, sedangkan rusak ringan mengakibatkan kerusakan setelah jangka waktu tertentu akibat dari genangan air laut. Lebih lanjut, kategori tidak ada kerusakan tidak mengakibatkan kerusakan atau kerugian pada properti masyarakat melainkan hanya mengakibatkan perubahan negatif garis pantai ke arah darat (Gracia et al., 2018; Roebeling et al., 2018). Meskipun demikian, perubahan garis pantai tersebut tetap harus dimonitor secara periodik sebagai upaya mitigasi bencana di wilayah kepesisiran (Lima et al., 2020; Rangel-Buitrago et al., 2018).

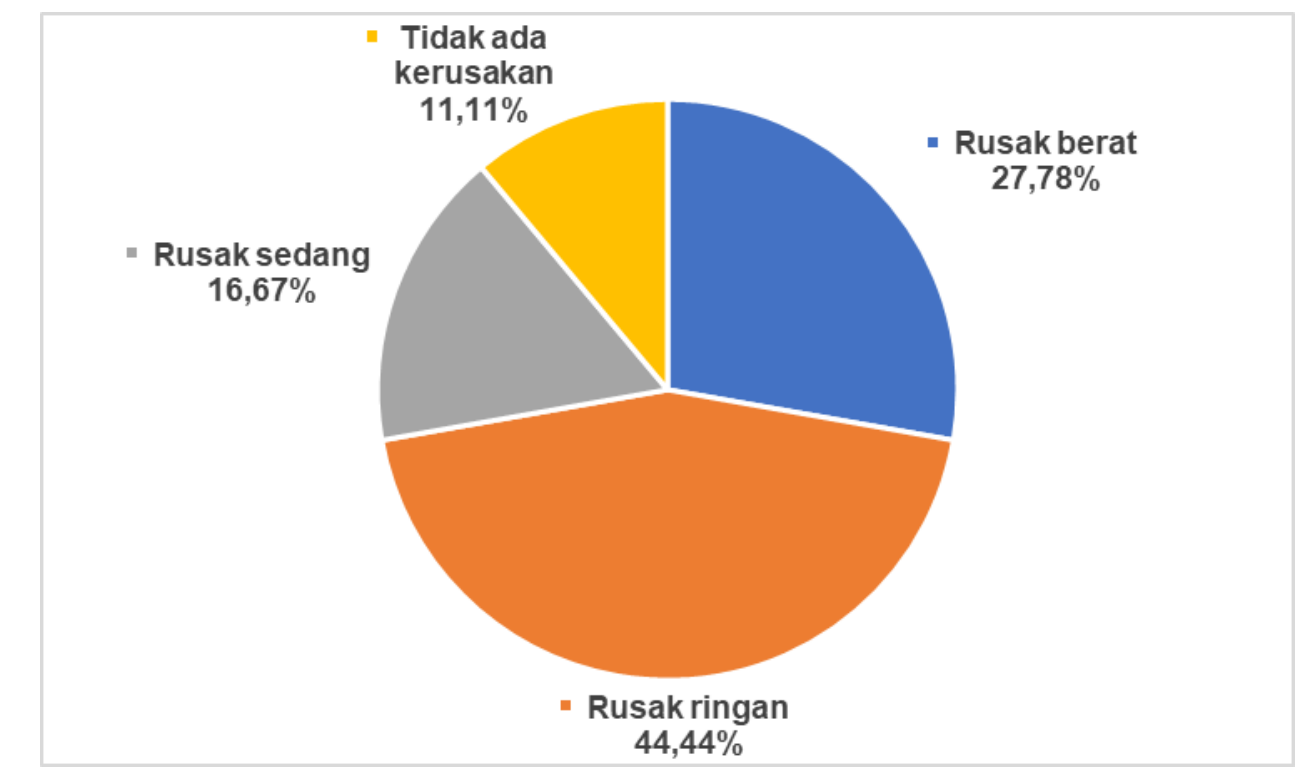

Gambar 2. Klasifikasi dampak kerusakan akibat erosi pantai atau abrasi di wilayah kepesisiran Kragan dan Sarang

Dampak kerusakan yang paling dominan adalah rusak ringan yang berarti bahwa terjadi perubahan garis pantai yang cukup signifikan (Gracia et al., 2018). Hal itu 
dipengaruhi oleh arah angin yang memicu perubahan kecepatan (kekuatan) dan arah arus laut yang mengakibatkan erosi pantai. Kerusakan tingkat berat mengakibatkan tidak hanya berakibat pada kerugian material saja tetapi juga memicu penurunan tingkat kesejahteraan masyarakat (Gomez et al., 2020; Mukhopadhyay et al., 2018). Hal itu dikarenakan, masyarakat terdampak dalam kategori berat harus mengalokasikan dana lebih untuk menangani kerusakan bangunan (rumah) yang ditempati. Selain itu, rusaknya pabrik dan tambak juga berdampak cukup fatal karena banyak masyarakat yang kehilangan penghasilan dan harus menanggung kerugian akibat abrasi (Senevirathna et al., 2018).

\section{Dampak Sosial Erosi Pantai}

Dampak erosi pantai atau abrasi terhadap masyarakat cenderung negatif karena mengakibatkan kerugian. Hasil wawancara dengan responden di lokasi terdampak menunjukkan bahwa dampak secara social sebenarnya menyeluruh secara psikologis, sosiologis (budaya) dan ekonomi (kesejahteraan) (Gambar 2) (Ardeshiri et al., 2019; Aswani, 2019; Bañas et al., 2020; Chiang \& Chang, 2018; Montero \& Batista, 2020; Nurhidayah \& Mcllgorm, 2019; Rahman \& Gain, 2020). Dampak secara psikologis mengakibatkan warga menjadi khawatir akan kehidupannya khususnya menyangkut permasalahan tempat tinggal dan mata pencaharian.

Dampak secara psikologis sangat dominan di lokasi studi baik wilayah terdampak dengan tingkat kerusakan berat atau tidak ada kerusakan. Hal itu karena secara spasial masyarakat tinggal di wilayah dengan karakteristik fisik yang sama, sehingga berpotensi terdampak abrasi. Oleh karena itu, meskipun tidak mengalami kerugian semua responden menyatakan sangat khawatir jika di kemudian hari terdampak abrasi (Domingues et al., 2018).

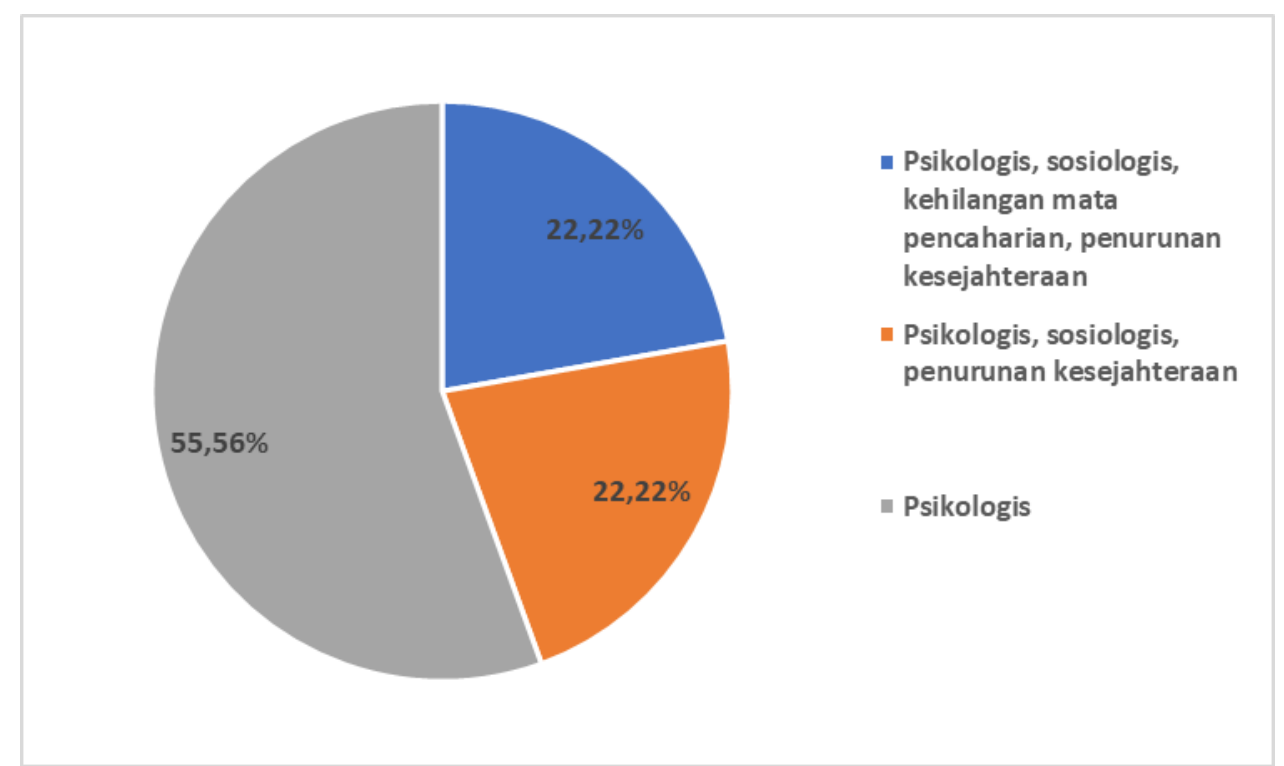

Gambar 3. Dampak sosial akibat erosi pantai atau abrasi di wilayah kepesisiran Kragan dan Sarang

Dampak secara psikologis sebenarnya merupakan dampak sekunder dari dampak fisik akibat abrasi. Kerugian pada bangunan, tambak maupun properti lainnya menyebabkan warga merasa was - was karena dihadapkan pada ancaman bencana yang berpotensi berakibat fatal di masa depan jika tidak ditanggulangi dengan cepat dan tepat (Domingues et al., 2018). Perasaan was - was warga yang paling dominan 
adalah pada kepastian tempat tinggal dan mata pencaharian jika dampak abrasi tidak dapat kunjung ditanggulangi.

Dampak sosiologis juga merupakan dampak sekunder akibat kerusakan fisik. Secara sosiologis masyarakat di wilayah terdampak abrasi akan cenderung berubah, baik pola kehidupan individu maupun secara kelompok (Rocle et al., 2020; Sangha et al., 2019). Secara individu masyarakat menjadi lebih tertutup dan kurang percaya diri dalam membaur dengan masyarakat yang tidak terdampak. Hal itu Sebagian karena alasan ekonomi dan perasaan rendah diri yang muncul akibat menjadi korban abrasi. Perubahan secara social kemasyarakatan terjadi pada kebiasaan-kebiasaan masyarakat sebelum dan setelah terdampak abrasi (Montero \& Batista, 2020; Rocle et al., 2020). Sebelum terdampak abrasi masyarakat aktif melaksanakan kegiatan social dan gotong royong tetapi setelah terdampak abrasi maka kegiatan social kemasyarakatan menjadi jauh berkurang. Hal itu karena masyarakat menjadi lebih fokus pada kehidupan pribadinya.

Dampak ekonomi jelas merupakan salah satu dampak yang paling dirasakan masyarakat (Aswani, 2019; Rahman \& Gain, 2020). Tanpa adanya kerusakan akibat abrasi, kondisi ekonomi khususnya kesejahteraan masyarakat wilayah kepesisiran Kragan dan Sarang berada pada level menengah ke bawah dengan mata pencaharian petani atau pekerja (buruh). Oleh karena itu, Ketika abrasi melanda dan mengakibatkan kerusakan yang serius akan meningkatkan penurunan kesejahteraan. Penurunan kesejahteraan akan diikuti oleh penurunan kualitas hidup baik dalam hal sandang, papan, pangan bahkan Pendidikan (Dávila et al., 2014). Dalam kondisi ekonomi yang sangat sulit, banyak anak-anak usia sekolah yang tidak bisa melanjutkan studi karena keterbatasan ekonomi orang tua.

\section{SIMPULAN}

Erosi pantai atau abrasi pada kondisi dan ruang tertentu dapat berdampak masif bagi kehiduoan masyarakat di wilayah kepesisiran Kragan dan Sarang, Kabupaten Rembang. Kerugian yang ditimbulkan adalah kerugian fisik dan sosial. Kerugian fisik selain perubahan garis pantai diklasifikasikan menjadi empat kategori, yaitu rusak berat, rusak sedang, rusak ringan dan tidak ada kerusakan. Rusak berat menjadi fokus utama karena mengakibatkan kerusakan properti berupa permukiman, pabrik, kantor pemerintahan dan tambak. Kerusakan property yang ditimbulkan oleh abrasi memang kurang dari $30 \%$ dari total jenis dampak yang ditimbulkan, tetapi ditinjau dari intensitas dan trennya bukan tidak mungkin wilayah dengan tingkat kerusakan sedang, rendah bahkan tidak ada kerusakan akan mengalami hal yang sama, jika fenomena tersebut tidak ditanggulangi. Lebih lanjut, dampak secara fisik, baik secara langsung maupun tidak langsung (sekunder) dapat mengakibatkan gangguan secara psikologis, sosiologis, ekonomi yang berimplikasi pada penurunan kesejahteraan dan tingkat pendidikan anak-anak terdampak abrasi. Oleh karena itu, diperlukan analisis yang lebih mendalam terhadap dampak erosi pantai atau abrasi sebagai Langkah awal mitigasi bencana kepesisiran.

\section{DAFTAR PUSTAKA}

Ahmed, A., Nawaz, R., Drake, F., \& Woulds, C. (2018). Modelling land susceptibility to erosion in the coastal area of Bangladesh: A geospatial approach. Geomorphology, 320, 82-97. https://doi.org/10.1016/j.geomorph.2018.08.004

Ardeshiri, A., Swait, J., Heagney, E. C., \& Kovac, M. (2019). Willingness-to-pay for coastline protection in New South Wales: Beach preservation management and decision making. Ocean and Coastal Management, 178(September 2018), 104805. https://doi.org/10.1016/j.ocecoaman.2019.05.007 
Aswani, S. (2019). Perspectives in coastal human ecology (CHE) for marine conservation. Biological Conservation, 236(February), 223-235. https://doi.org/10.1016/j.biocon.2019.05.047

Bañas, J. C. C., Subade, R. F., Salaum, D. N., \& Posa, C. T. (2020). Valuing vanishing coasts: The case of Miagao coastline in Southern Iloilo, Philippines. Ocean and Coastal Management, 184(March), 105008. https://doi.org/10.1016/j.ocecoaman.2019.105008

BNPB. (2012). Peraturan Kepala Badan Nasional Penanggulangan Bencana Nomor 02 Tahun 2012 tentang Pedoman Umum Pengkajian Risiko Bencana (p. 62). BNPB.

BPS (The Indonesian Central Bureau for Statistics). (2014). Rembang Regency in Numbers 2014. Central Bureau for Statistics.

Chiang, Y. C., \& Chang, H. P. (2018). Cultural dimensions of risk perceptions: A case study on cross-strait driftage pollution in a coastal area of Taiwan. Journal of Environmental Management, 206, 123-133. https://doi.org/10.1016/j.jenvman.2017.10.010

Davidson-Arnott, R. (2010). Introduction to Coastal Processes and Geomorphology. Cambridge University Press.

Dávila, O. G., Stithou, M., Pescaroli, G., Pietrantoni, L., Koundouri, P., Díaz-Simal, P., Rulleau, B., Touili, N., Hissel, F., \& Penning-Rowsell, E. (2014). Promoting resilient economies by exploring insurance potential for facing coastal flooding and erosion: Evidence from Italy, Spain, France and United Kingdom. Coastal Engineering, 87, 183-192. https://doi.org/10.1016/j.coastaleng.2013.12.007

Dewi, R. S., \& Bijker, W. (2020). Dynamics of shoreline changes in the coastal region of Sayung, Indonesia. Egyptian Journal of Remote Sensing and Space Science, 23(2), 181-193. https://doi.org/10.1016/j.ejrs.2019.09.001

Domingues, R. B., Santos, M. C., de Jesus, S. N., \& Ferreira, Ó. (2018). How a coastal community looks at coastal hazards and risks in a vulnerable barrier island system (Faro Beach, southern Portugal). Ocean and Coastal Management, 157(November 2017), 248-256. https://doi.org/10.1016/j.ocecoaman.2018.03.015

Dunning, K. H. (2020). Building resilience to natural hazards through coastal governance: a case study of Hurricane Harvey recovery in Gulf of Mexico communities. Ecological Economics, 176(May), 106759. https://doi.org/10.1016/j.ecolecon.2020.106759

Gomez, M. L. A., Adelegan, O. J., Ntajal, J., \& Trawally, D. (2020). Vulnerability to coastal erosion in The Gambia: Empirical experience from Gunjur. International Journal of Disaster Risk Reduction, 45(August 2019), 101439. https://doi.org/10.1016/j.ijdrr.2019.101439

Gracia, A., Rangel-Buitrago, N., Oakley, J. A., \& Williams, A. T. (2018). Use of ecosystems in coastal erosion management. Ocean and Coastal Management, 156, 277-289. https://doi.org/10.1016/j.ocecoaman.2017.07.009

Kerguillec, R., Audère, M., Baltzer, A., Debaine, F., Fattal, P., Juigner, M., Launeau, P., Le Mauff, B., Luquet, F., Maanan, M., Pouzet, P., Robin, M., \& Rollo, N. (2019). Monitoring and management of coastal hazards: Creation of a regional observatory of coastal erosion and storm surges in the pays de la Loire region (Atlantic coast, France). Ocean and Coastal Management, 181(January). https://doi.org/10.1016/j.ocecoaman.2019.104904

Landry, C. E., Shonkwiler, J. S., \& Whitehead, J. C. (2020). Economic Values of Coastal Erosion Management: Joint Estimation of Use and Existence Values with recreation demand and contingent valuation data. Journal of Environmental Economics and Management, 103, 102364. https://doi.org/10.1016/j.jeem.2020.102364

Leatherman, S. P. (2018). Coastal Erosion and the United States National Flood Insurance Program. Ocean and Coastal Management, 156, 35-42. 
https://doi.org/10.1016/j.ocecoaman.2017.04.004

Lima, M., Coelho, C., Veloso-Gomes, F., \& Roebeling, P. (2020). An integrated physical and cost-benefit approach to assess groins as a coastal erosion mitigation strategy. Coastal Engineering, 156, 103614. https://doi.org/10.1016/j.coastaleng.2019.103614

Marchesiello, P., Nguyen, N. M., Gratiot, N., Loisel, H., Anthony, E. J., Dinh, C. S., Nguyen, T., Almar, R., \& Kestenare, E. (2019). Erosion of the coastal Mekong delta: Assessing natural against man induced processes. Continental Shelf Research, 181(May), 72-89. https://doi.org/10.1016/j.csr.2019.05.004

Marfai, M. A., \& King, L. (2008). Potential vulnerability implications of coastal inundation due to sea level rise for the coastal zone of Semarang city, Indonesia. Environmental Geology, 54(6), 1235-1245. https://doi.org/10.1007/s00254-0070906-4

Montero, O. P., \& Batista, C. M. (2020). Social perception of coastal risk in the face of hurricanes in the southeastern region of Cuba. Ocean and Coastal Management, 184(xxxx), 105010. https://doi.org/10.1016/j.ocecoaman.2019.105010

Mukhopadhyay, A., Ghosh, P., Chanda, A., Ghosh, A., Ghosh, S., Das, S., Ghosh, T., \& Hazra, S. (2018). Threats to coastal communities of Mahanadi delta due to imminent consequences of erosion - Present and near future. Science of the Total Environment, 637-638(2018),

717-729. https://doi.org/10.1016/j.scitotenv.2018.05.076

Muria News. (2014). Abrasi Rembang Kian Parah. https://www.google.com/search?q=abrasi+rembang+Muria+News\%2C+29+Janua ri+2014\&rlz=1C1CHBF_enID907ID907\&oq=abrasi+rembang+Muria+News\%2C+2 9+Januari+2014\&aqs=chrome..69i57.9809j0j7\&sourceid=chrome\&ie=UTF-8

Nadzir, N. M., Ibrahim, M., \& Mansor, M. (2014). Impacts of Coastal Reclamation to the Quality of Life: Tanjung Tokong Community, Penang. Procedia - Social and Behavioral Sciences, 153, 159-168. https://doi.org/10.1016/j.sbspro.2014.10.050

Nurhidayah, L., \& Mcllgorm, A. (2019). Coastal adaptation laws and the social justice of policies to address sea level rise: An Indonesian insight. Ocean and Coastal Management, 171(February 2018), 11-18. https://doi.org/10.1016/j.ocecoaman.2019.01.011

Rahman, M. S., \& Gain, A. (2020). Adaptation to river bank erosion induced displacement in Koyra Upazila of Bangladesh. Progress in Disaster Science, 5, 100055. https://doi.org/10.1016/j.pdisas.2019.100055

Rangel-Buitrago, N., de Jonge, V. N., \& Neal, W. (2018). How to make Integrated Coastal Erosion Management a reality. Ocean and Coastal Management, 156(January), 290-299. https://doi.org/10.1016/j.ocecoaman.2018.01.027

Rangel-Buitrago, N., Neal, W. J., \& de Jonge, V. N. (2020). Risk assessment as tool for coastal erosion management. Ocean and Coastal Management, 186(January), 105099. https://doi.org/10.1016/j.ocecoaman.2020.105099

Rocle, N., Rey-Valette, H., Bertrand, F., Becu, N., Long, N., Bazart, C., Vye, D., MeurFerec, C., Beck, E., Amalric, M., \& Lautrédou-Audouy, N. (2020). Paving the way to coastal adaptation pathways: An interdisciplinary approach based on territorial archetypes. Environmental Science and Policy, 110(May), 34-45. https://doi.org/10.1016/j.envsci.2020.05.003

Roebeling, P., d'Elia, E., Coelho, C., \& Alves, T. (2018). Efficiency in the design of coastal erosion adaptation strategies: An environmental-economic modelling approach. Ocean and Coastal Management, 160(April), 175-184. https://doi.org/10.1016/j.ocecoaman.2017.10.027

Rumson, A. G., Hallett, S. H., \& Brewer, T. R. (2017). Coastal risk adaptation: the potential role of accessible geospatial Big Data. Marine Policy, 83(March), 100110. https://doi.org/10.1016/j.marpol.2017.05.032 
Sánchez-García, E., Balaguer-Beser, A., \& Pardo-Pascual, J. E. (2017). C-Pro: A coastal projector monitoring system using terrestrial photogrammetry with a geometric horizon constraint. ISPRS Journal of Photogrammetry and Remote Sensing, 128, 255-273. https://doi.org/10.1016/j.isprsjprs.2017.03.023

Sangha, K. K., Stoeckl, N., Crossman, N., \& Costanza, R. (2019). A state-wide economic assessment of coastal and marine ecosystem services to inform sustainable development policies in the Northern Territory, Australia. Marine Policy, 107(April), 103595. https://doi.org/10.1016/j.marpol.2019.103595

Senevirathna, E. M. T. K., Edirisooriya, K. V.D., Uluwaduge, S. P., \& Wijerathna, K. B. C. A. (2018). Analysis of Causes and Effects of Coastal Erosion and Environmental Degradation in Southern Coastal Belt of Sri Lanka Special Reference to Unawatuna Coastal Area. Procedia Engineering, 212, 1010-1017. https://doi.org/10.1016/j.proeng.2018.01.130

Sinitsyn, A. O., Guegan, E., Shabanova, N., Kokin, O., \& Ogorodov, S. (2020). Fifty four years of coastal erosion and hydrometeorological parameters in the Varandey region, Barents Sea. Coastal Engineering, 157, 103610. https://doi.org/10.1016/j.coastaleng.2019.103610

Sun, X., Zhang, L., Lu, S. Y., Tan, X. Y., Chen, K. L., Zhao, S. Q., \& Huang, R. H. (2020). A new model for evaluating sustainable utilization of coastline integrating economic output and ecological impact: A case study of coastal areas in Beibu Gulf, China. Journal of Cleaner Production, 271. https://doi.org/10.1016/j.jclepro.2020.122423

Toimil, A., Camus, P., Losada, I. J., Le Cozannet, G., Nicholls, R. J., Idier, D., \& Maspataud, A. (2020). Climate change-driven coastal erosion modelling in temperate sandy beaches: Methods and uncertainty treatment. Earth-Science Reviews, 202(June 2019), 103110. https://doi.org/10.1016/j.earscirev.2020.103110

Trembanis, A., Lundine, M., \& McPherran, K. (2020). Coastal Mapping and Monitoring. In Reference Module in Earth Systems and Environmental Sciences (2nd ed.). Elsevier Inc. https://doi.org/10.1016/b978-0-12-409548-9.12466-2

Triyanti, A., Bavinck, M., Gupta, J., \& Marfai, M. A. (2017). Social capital, interactive governance and coastal protection: The effectiveness of mangrove ecosystembased strategies in promoting inclusive development in Demak, Indonesia. Ocean and Coastal Management, 150, 3-11. https://doi.org/10.1016/j.ocecoaman.2017.10.017

Venancio, K. K., Garcia, P. D., Gireli, T. Z., \& Corrêa, T. B. (2020). Hydrodynamic modeling with scenario approach in the evaluation of dredging impacts on coastal erosion in Santos (Brazil). Ocean and Coastal Management, 195(August). https://doi.org/10.1016/j.ocecoaman.2020.105227

Wibowo, Y. A., Ronggowulan, L., Arif, D. A., Afrizal, R., Anwar, Y., \& Fathonah, A. (2019). Perencanaan Mitigasi Bencana Banjir Non-Struktural Di Daerah Aliran Sungai Comal Hilir, Jawa Tengah. JPIG (Jurnal Pendidikan Dan IImu Geografi), 4(2), 87-100. https://doi.org/10.21067/jpig.v4i2.3632

Yin, P., Duan, X., Gao, F., Li, M., Lü, S., Qiu, J., \& Zhou, L. (2018). Coastal erosion in Shandong of China: status and protection challenges. China Geology, 1(4), 512521. https://doi.org/10.31035/cg2018073 